\title{
Social Tolerance and Racist Materials in Public Libraries
}

When asked about a hypothetical book containing racist beliefs, do people support removing the book from their public library or not? The study examined responses to this question from surveys conducted from 1976 to 2006. Responses were analyzed for changes over time and for differences between demographic categories of respondents. Data were gathered by the General Social Survey, a well-respected social sciences data resource.

How much we value the right of free speech is put to its severest test when the speaker is someone we disagree with most.

-American Civil Liberties Union, "Hate Speech on Campus"

ibrarians are against censorship in principle and advocate against censorship in many ways, such as the American Library Association's (ALA) annual Banned Books Week and various activities by intellectual freedom committees of state and national organizations. But does this advocacy extend to all types of materials? What about literature that is "negative" or of questionable accuracy, such as Herrnstein and Murray's The Bell Curve (Free Press, 1994), holocaust denial literature, or other literature that denigrates racial or ethnic groups? Does this literature belong in public libraries? The following literature review summarizes three areas of thought to form a framework from which to examine the concept of books with racist content in public libraries. First is an introduction to the concept of intellectual freedom in libraries. This is followed by a brief review of library and information studies (LIS) literature concerning racism in library books. Most of this literature has concerned children's materials, although children's materials are not the focus of this study. Last is a brief introduction to scholarly thought from different disciplines concerning racist speech or hate speech and whether such speech should be controlled. The paper then uses data analysis to examine the opinions of the U.S. population on the idea of racism in library books, and concludes with a discussion of similarities and differences between the opinions of the experts and scholars as presented in the literature review and the opinions of the general population as examined in the data analysis section.

\section{LIBRARY VALUES AND INTELLECTUAL FREEDOM}

If there exists a right to express an opinion, then there also exists a right to know about that opinion.

\section{Susan K. Burke}

Susan K. Burke is Assistant Professor, School of Library and Information Studies, University of Oklahoma, Norman. Submitted for review April 18, 2009; revised and accepted for publication September 18, 2009.
Reference \& User Services Quarterly, vol. 49, no. 4 pp. 369-379 (c) 2010 American Library Association. All rights reserved.

Permission granted to reproduce for nonprofit, educational use. 


\section{FEATURE}

Where else but in the library, and especially in the public library, can all citizens avail themselves of that right?

-John Robotham and Gerald

Shields, Freedom of Access to Library Material

The library literature abounds with expression of the centrality of intellectual freedom to the mission of libraries. Some examples include Immroth's statement that "intellectual freedom is considered a basic principle of modern American library practice." Saunders similarly declared that "intellectual freedom is a concept at the very core of professional librarianship."2 ALA's Library Bill of Rights, adopted more than fifty years ago, emphasizes that "materials should not be excluded because of the origin, background, or views of those contributing to their creation." ${ }^{\text {3 Salak }}$ worded this assertion somewhat differently: "If a public library is doing its job, it has something in it that offends every single person." ${ }^{4}$

Conversely, some library experts have cautioned that librarians must carefully consider whether to include controversial materials in their collections. For example, in 1967 Shera said,

When a librarian really believes that a book is harmful, that its content is contrary to the welfare of the community, or that it is destructive of good taste, even if those are his opinions only, he has not only the right, but also the obligation to do what he properly can to keep that book out of the hands of those whom he thinks might be injured by it. ${ }^{5}$

Where is the line between harmful books that do not belong in libraries, as described by Shera, and offensive books that do belong in libraries, as indicated by Salak? Estabrook and Horak, in a survey conducted in 1991, found that there were differences of opinion between librarians and the public. Particularly, the study found the public to be more conservative than librarians concerning materials on controversial topics in libraries. ${ }^{6}$

Is the difference in opinion between librarians and the public about controversial books predominately tied to the age of the intended audience? According to the ALA Office of Intellectual Freedom's (OIF) database of challenged books, most of the challenges received in libraries are to materials for children. ${ }^{7}$ While parents may want librarians to monitor their children's reading materials, the Library Bill of Rights advocates free access to information for all age levels, and librarians expect parents to be responsible for monitoring their children's book choices at the library. ${ }^{8}$ At issue is the conflict between those that believe exposure to controversial ideas is harmful versus those that believe that exposure to a variety of viewpoints teaches readers to be critical thinkers. ${ }^{9}$ Some writers advocate that free access to information from an early age leads children to be able to discard negative depictions and stand by morals and values taught by their parents, while others "have argued that public libraries and public school educators... have a responsibility to inculcate values."10 According to Willett, "Librarians tend to share the general adult belief that children need guidance in matters of literary quality and appropriateness" and take their positions as transmitters of cultural heritage seriously. ${ }^{11}$ One of the difficulties in this task is that different adults have different views about what values are important and what ideas are appropriate. Steinle suggests that teaching values, beliefs, and ideals to children is the most important responsibility of society, but that cultural behavior and expectations change and have made this enculturation more difficult in the last several decades. ${ }^{12}$

\section{RACISM IN LIBRARY BOOKS}

Sova included racist literature in the category of literature that has met social opposition for containing vulgar expressions unacceptable to community standards and that challengers view as harmful to readers. ${ }^{13}$ Most of the discussions in the library literature of racism in books concerns controversial images or depictions in children's literature. Ashmore, for example, discussed the historical roots of concern for positive images in literature for African American children, particularly the writings of $\mathrm{Du}$ Bois and Dill in 1919. She went on to discuss other early criticisms of negative portrayals of African Americans in children's literature, such as the work of Charlemae Hill Rollins. ${ }^{14}$ Pescosolido, Grauerholz, and Milkie analyzed African Americans in U.S. children's picture books in three sets from 1937 to 1993 and concluded that depictions of African Americans varied significantly over time..$^{15}$ Taylor discussed books that she enjoyed as a child, but when she was reintroduced to them as an adult she realized that they were blatantly racist. ${ }^{16}$ Willett's analysis of the social climate that surrounded proposed changes due to racial issues to Rifles for Watie, an award-winning children's book in 1958, detailed the complex interactions of current social issues, history, and the viewpoints of librarians, authors, and publishers in the judgment of a book's contents. ${ }^{17}$

An example of an adult book that generated a great deal of controversy for its purported racism is The Bell Curve: Intelligence and Class Structure in American Life, which was published in 1994. Fraser called it "clearly the most incendiary piece of social science to appear in the last decade or more." ${ }^{\prime 8}$ Librarians have not shied away from adding this controversial book to their collections. An OCLC search for the book in all formats revealed 4,276 holdings, and even more holdings for the several books subsequently published to refute the claims of The Bell Curve.

According to the OIF's database of challenged books, only 3 percent of reported challenges from 1990 to 2005 were for racism $\left(353\right.$ of 12,342). ${ }^{19}$ Other challenges for racism might be obscured under a different label, as Burress explains: "Many objections to racist material are hidden under objections to language," such as bad language or obscenity. ${ }^{20}$ Offensive language was the second most common reason for 
censorship attempts reported to ALA (2,073 attempts, or 17 percent $).{ }^{21}$

In discussing state and national political organizations that have been accused of censorship, Clay mentioned several conservative groups, but he also pointed out that liberal political groups have challenged materials in educational settings. For example, the National Association for the Advancement of Colored People and the Council on International Books for Children both took a stance against books in libraries considered racist, such as Little Black Sambo. ${ }^{22}$

\section{THOUGHTS FROM OUTSIDE LIBRARY AND INFORMATION STUDIES}

Racism and hate speech are topics of study in a variety of disciplines, including sociology, political science, and literary studies. In these fields opinions are divided, with some authors supporting a constitutional right to engage in hate speech and others asserting hate speech should not be allowed. While racism is a very broad term that encompasses a wide range of actions by individuals and institutions, racist hate speech is a form of racism that appears in words. Wolfson pointed out that hate speech is difficult to define, "but it generally includes offensive speech directed at minorities. In its most vulgar form, it includes the racial and sexist epithet. . . At a more subtle level ... it includes books, cinema, and television images that demean a minority." ${ }^{23}$ Parekh cautioned that not all offensive or unacceptable racist speech is hate speech. While speech may be insulting, abusive, or denigrating, to be defined as hate speech it must in some manner express, advocate, or promote hatred of a group of people. ${ }^{24}$

The First Amendment guarantee of freedom of speech is a cornerstone of American democracy. While the norms of social politeness may limit most people's racial commentary in public venues, their constitutional right to make inflammatory statements is protected. The American Civil Liberties Union, in expressing concern over limitations on hate speech imposed on college campuses in the 1990s, stated, "Speech that deeply offends our morality or is hostile to our way of life warrants the same constitutional protection as other speech because the right of free speech is indivisible: When one of us is denied this right, all of us are denied." 25 Wolfson was also concerned about college campus speech bans and stated, "Hate speech is criticized as lacking any of the elements that warrant constitutional protection. Hence, scores of universities have enacted speech codes that ban hate speech." 26 He also wrote, "If we ban racist speech, how then do we not move inexorably to the suppression of other unpopular thought?"27

In addition to arguments protecting the rights of free speech for legal reasons, some writers point out that children need to be exposed to varieties of social and ethnic intolerance so that they can learn to reject negative connotations and think critically about the things other people say. For example, Judge Stephen Reinhardt said in Monteiro v. The Tempe Union High School District that while words can hurt, particularly racist epithets, "a necessary component of any education is learning to think critically about offensive ideas-without that ability, one can do little to respond to them." ${ }^{\text {"28 }}$ In reminiscing about being called a "dirty Jew" in his childhood, White said "I cannot believe that all these so-called victims of hate speech possess fewer resources or intelligence or simple moxie than an eleven-year old child so that their lives will fall into ruin because of the words some fool utters." 29

Laura Beth Nielson, professor of sociology and law, disagreed with the idea of the equal rights of hate speech to be noncensored: "Why has this society, which has shown increasing sensitivity to the legal protection of traditionally disadvantaged groups, continued to afford constitutional protection to offensive public speech?"30 Weinstein asserted that critical race theorists challenge the claims that free speech offers intellectual neutrality. He stated that "racist speech is used to intimidate, degrade, and silence people of color and thus is an important mechanism by which minorities are subordinated." ${ }^{31}$ Myers called this speech "racetalk" and defined it as "the vocabulary and conceptual frameworks that we use to denigrate different races and ethnicities in our everyday lives." 32 She stated that not only is racetalk offensive, it is injurious, contagious, and all-pervasive. While Myers was studying verbalized racetalk, the types of utterances which she recorded in her research were the same types of phrases that are frequently considered inflammatory in written literature.

Parekh advocated a ban on hate speech in the United States and stated that many countries have such bans, including Britain, Denmark, Canada, the Netherlands, Australia, Germany, India, and Israel. While the specifics in each country vary, in general the bans affect inflammatory speech toward racial, religious, or other groups. Parekh supported such a ban in the United States on the argument that the impact of hate speech deeply affects the lives of the targeted groups, including affecting individuals' ability to live without fear and harassment and affecting the pursuit of activities or occupations that they might otherwise pursue. ${ }^{33}$

\section{SUMMARY AND PROBLEM STATEMENT}

Support for intellectual freedom and for the inclusion of controversial ideas in libraries is strong in the library profession. There is some likelihood that materials for children might undergo more stringent screening for appropriateness, and treatments of racism in books in the library literature is predominately focused on literature for children. Scholars in other disciplines are divided in their attitudes toward regulation of the expression of racist ideas, and the sampling of thoughts on racist speech presented here echoes experts' opinions on the state of racism in the United States as a whole. Bloom referred to it as "the apparent schizophrenia in elite opinion on the current status of American racial attitudes and conditions. ${ }^{34}$ Public libraries regularly receive challenges to their materials from members of their communities, and little has been writ- 


\section{FEATURE}

ten in the library literature about how the general public feels toward materials with racist content in public library collections. This study is intended to present librarians with public opinion data on the matter within a framework of scholarly viewpoints and may be useful when facing collection development decisions, materials challenges, or other decision-making regarding potentially controversial material.

Following is the problem statement on which this study was based: Most LIS writers support the right to include books in library collections, even if those materials advocate racist or other controversial viewpoints. Scholars in other disciplines advocate both for and against equal protections for racially offensive speech. Within the library literature little has been done to ascertain how public library constituencies feel about these materials in public library collections. What are the general public's levels of social tolerance toward materials with racist content in public library collections?

There were six questions guiding our research:

1. Did a majority of respondents support removing a racist's book from their public library?

2. Did support for removing a racist's book change over the thirty-year period covered in the data?

3. Did demographic factors affect respondents' opinions concerning book removal?

4. Did geographic factors, such as region of the country and place size, affect respondents' opinions concerning book removal?

5. What personal belief systems are tied to people's opinions on book removal?

6. Did occupation affect respondents' opinions on book removal?

\section{METHOD}

The General Social Survey (GSS) conducted by the National Opinion Research Center is one of the most respected and used social science trend studies in the United States. Initiated in
1972, this closed-ended survey queries probability samples of U.S. noninstitutionalized adults age eighteen and older about their opinions of social issues and includes a variety of demographic measures..$^{35}$ In the early to mid-1970s, concern for social and racial equality prompted the inclusion of a variety of survey questions concerning racial tensions between African Americans and whites on a variety of issues. The GSS questions concerning controversial books in libraries are part of a social tolerance measure that also includes questions about people with controversial ideas being allowed to speak publicly and teach in colleges. From 1976 to 2006, the GSS asked randomly selected national samples of U.S. adults whether they would support removing a book spouting racist beliefs from the public library. Surveys were conducted irregularly, sometimes annually and sometimes every two or three years. In total, this question was asked nineteen times in thirty years. Respondents were also asked a wide variety of demographic questions, such as age, race, sex, religious affiliation, political beliefs, education level, geographic location, and more. Up to 2004, only Englishspeaking respondents were surveyed, but starting in 2006, Spanish speakers were included. ${ }^{36}$

The dependent variable used in this study was the following survey question:

There are always some people whose ideas are considered bad or dangerous by other people. ... consider a person who believes that Blacks are genetically inferior? If some people in your community suggested that a book he wrote which said Blacks are inferior should be taken out of your public library, would you favor removing this book, or not $?^{39}$

The terms used in this question changed as social acceptance of various terms evolved. The wording changed from "Negroes" in 1972 to "Negroes/ Blacks" to "Blacks/Negroes" to "Blacks/ African Americans." ${ }^{40}$ For the purposes of this analysis, "African Americans" will be used. Over the thirty-year period of the study, 26,798 respondents answered the question about whether they would support removing the racist's book from the library.

The majority of the variables used in the study were nominal-level, and a few were ordinal. As suggested in the codebook, the author used the weighting variable WTSSALL during statistical calculations to correct for sample design variations. Data were examined using percentages in multilevel crosstabulations. In addition to percentages, chi-square for independence using frequencies was calculated. Regression was also used.

Statistical tests of significance, such as chi-square, serve to determine whether a difference depicted in the data reflect an actual difference in the population, or whether the difference could have occurred by chance alone. Therefore to state that something is statistically significant is not stating that it is important, as the word "significant" does not mean "important" in this usage. As sample sizes increase, the sample values become more likely to approximate the population values. Very small differences thus become statistically significant because it becomes increasingly likely that the sample is reflective of the population. In the case of a sample as large as that used in this study-more than twenty-six thousand respondents-very small differences in percentages are statistically significant at the .000 level. In such cases, the researcher has to make a judgment call in deciding whether such small differences are meaningful. While the sample size is very large, dividing the data into multilayer cross-tabulations reduces the subcategories into much smaller samples in some instances. In these cases, the significance test becomes more informative.

\section{Limitations of the Study}

The GSS is a valuable dataset because it offers data that can be analyzed for change over time and used to observe trends in social issues. Collecting data over time is difficult and expensive, so 
using a dataset such as the GSS is efficient and useful. There are, however, some limitations to using available data such as these. The survey questions that were asked of respondents during data collection were designed by someone other than the current researcher. Additional questions might have been more useful for a LIS analysis. For example, opinion polls measure respondents' opinions or beliefs, not their actions. Research has shown that people may or may not act in accordance to their beliefs, and GSS respondents were only asked whether they would support book removal, not if they had actually participated in a challenge. Respondents in this study were not asked if they were library users. Additionally, it would have been useful to differentiate between books for adults and books for children. Finally, the question only asked about racist beliefs against African Americans and not other minority groups.

\section{DATA ANALYSIS}

The data analysis addressed six research questions. The first and most basic question was, "Did a majority of respondents support removing a racist's book from their public library?" The answer to this question was no. Only 35.3 percent of 26,796 respondents stated that they would support removing the racists' book from the library; thus the majority of respondents (64.7 percent) did not support removing the book.

The second research question was, "Did support for removing a racist's book change over the thirty-year period covered in the data?" In 1976, the first year that this question was asked, 38.1 percent of respondents supported removing the book from the library. In 2006, 34.5 percent were in support. The lowest level of support was 31.8 percent in 1994, and the highest was 41.6 percent in 1982. All other years were between 32.4 and 38.1 percent in support of removal. While these differences were statistically significant with chi-square for independence using frequencies, the significance is an artifact of the very large sample size. The 2006 rate of support for removal was only
3.6 percentage points less than the rate of support in 1976. This is not a truly meaningful or important difference. The rate of support for removal was approximately the same in 2006 as it was thirty years earlier (see figure 1).

To clarify trends for additional analysis, the author combined years into three groups, representing the early (1976-85, N = 13,985), middle (1986$95, \mathrm{~N}=13,794)$, and later $(1996-2006$, $\mathrm{N}=18,640$ ) years of the study. In these groups, rates of support for removal were 37.4 percent, 34.1 percent, and 34.3 percent, respectively. Collapsing categories in this manner does result in a loss of detailed information, but it is helpful for making the data less complex and for highlighting trends.

\section{Demographic and Geographic Analysis}

The third research question was, "Did demographic factors impact respondents' opinions concerning book removal?" Education level, race, age, parental status, and sex were analyzed in this section. For most independent variables there was little change over time in opinions about book removal, so change over time was only discussed in the data analysis for the variables for which it was relevant.

Education level had a strong impact on opinions concerning book removal. Half (50.6 percent) of respondents with less than a high school education

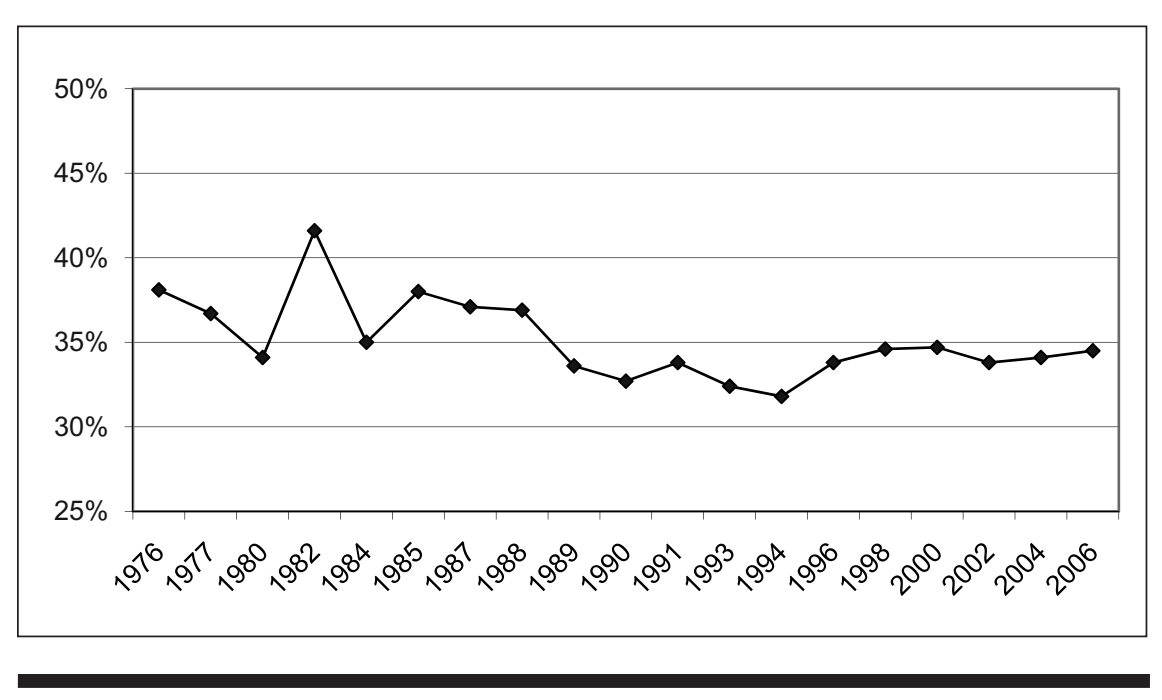

Figure 1. Support for Removing Racist's Book by Year
$(\mathrm{N}=5,740)$ supported removal compared with one-third (35.8 percent) of those with high school diplomas (N $=14,239), 29.2$ percent of those with a junior college degree $(N=1,412)$, 20.5 percent of those with bachelor's degrees $(\mathrm{N}=3,641)$, and 15.3 percent of those with graduate degrees $(\mathrm{N}=$ 1,686). Differences by education level were significant at the .000 level. Across the years of the study, respondents with high school diplomas maintained their level of support for book removal, but respondents with education levels beyond high school increased their support of book removal. Those with junior college and bachelor's degrees became more likely to support removal by 5 to 6.5 points. Respondents with graduate degrees changed their opinions most by increasing support for removal by 9.8 points, from 9.5 percent in the early years to 19.3 percent in the later years of the study. Respondents with less than high school degrees reduced their support of book removal by 5.7 points. By year, differences by education were significant at the .000 level.

For the GSS, race was interviewercoded from 1972 to 2000 as "white," "black," or "other." In 2002, the GSS switched to asking race using the U.S. Census Bureau categories. In the analysis, unsurprisingly, race was strongly related to opinions on removing the offensive book. One-half of African American respondents ( $N=3,690)$ supported the book's removal, compared to 


\section{FEATURE}

one-third of the white respondents (50 percent; $\mathrm{N}=21,767)$. There was little variation in whites' opinions over the years, ranging from 31.1 to 34.1 percent, while African Americans varied slightly from 53.4 percent in the early years, dropping to 45.8 percent in the middle, and rising to 49.8 percent in the later years. For a more detailed picture of opinions, the author examined support for removal using a combination of education level, race, and year. The patterns previously discussed both for education level and race were reproduced. African Americans with less than a high school education supported removal at a rate of 63.3 percent in the early years, dropping to 57.9 percent in the later years of the study $(\mathrm{N}=$ $1,915)$. White respondents at this education level supported removal at 51.5 percent, dropping to 45.2 percent $(\mathrm{N}$ $=4,204)$. For high school graduates, African Americans supported removal at 50.4 percent rising to 52.4 percent, and white respondents supported removal at 32.8 percent rising to 33.1 percent (African Americans $\mathrm{N}=1,915$; whites $N=11,732$ ). African Americans with junior college degrees supported removal at 34.2 percent to 33.7 percent, and white respondents at this level were supportive at 23.6 percent rising to 30.8 percent (African Americans $\mathrm{N}=197$; whites $\mathrm{N}=1,134)$. At the bachelor's level, African Americans supported removal at 30.8 percent in the early years rising to 33.6 percent, compared to white respondents at 17.3 percent rising to 22.5 percent (African Americans $\mathrm{N}=272$; whites $\mathrm{N}=3,171$ ). For those with graduate degrees, African Americans supported removal in the early years at 20.5 percent rising to 31.6 percent, compared to white respondents at 7.8 percent rising to 16.7 percent (African Americans $\mathrm{N}=113$; whites $\mathrm{N}=1,470)$. These differences were statistically significant except for African American respondents with junior college degrees, who showed no significant change from the early to the later years of the study (see figure 2).

Concerning age, the mean age was 44.1 years, and the median age was 42 years. For analysis, the author placed ages into four approximately equal-sized

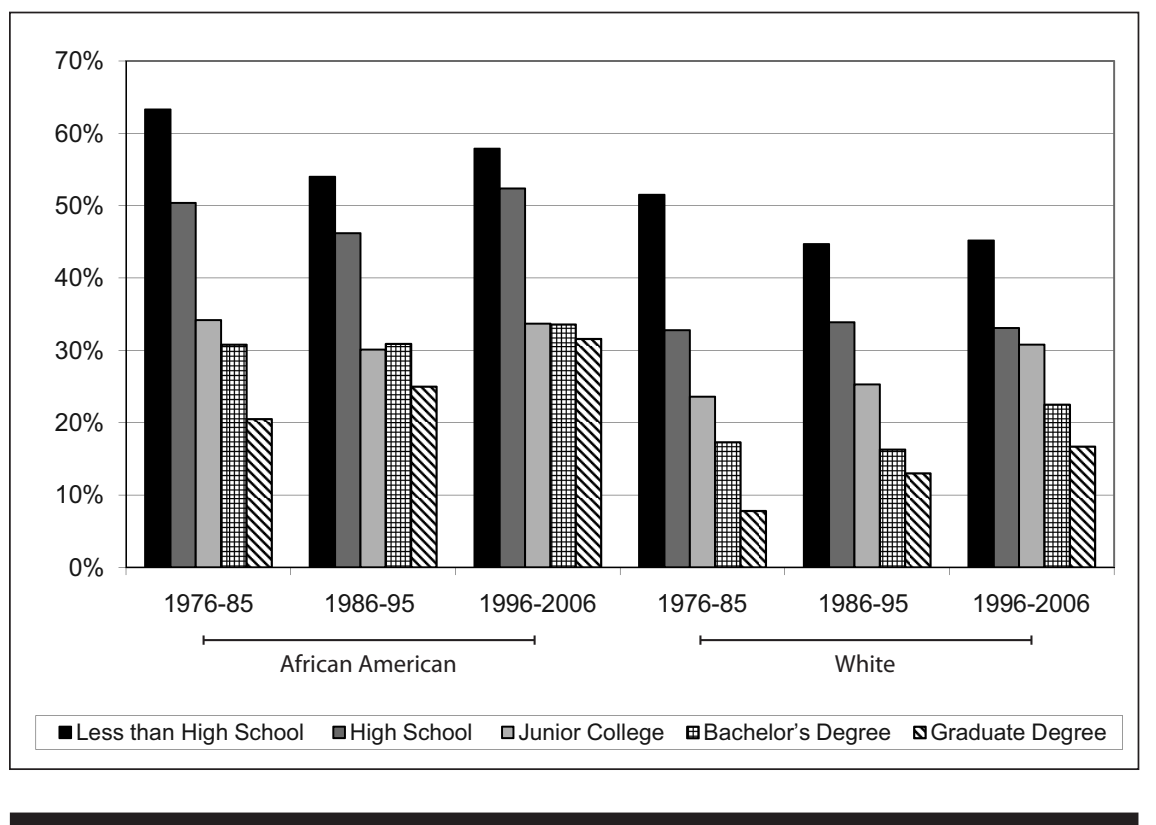

Figure 2. Support for Removing Racist's Book by Race (African American and White Respondents), Education Level, and Year

groups: $18-29(\mathrm{~N}=12,254), 30-42(\mathrm{~N}$ $=13,658), 43-56(\mathrm{~N}=12,450)$, and 57 and older $(\mathrm{N}=12,505)$. Respondents over 57 were slightly more likely to support removal (43.5 percent) than the younger respondents (31.1-34.1 percent). There was change over time within age groups as cohorts aged into subsequent groupings. Those in the 18-29 age range remained at one-third supporting in both the early and the later years of the study. Those 30-42 supported removal at 29.8 percent in the early years and 34.1 percent in the later years. Those 43-56 supported removal at 37.1 percent in the early years falling to 31.2 percent in the later years. The largest change was seen in those 57 and older, whose support for removal dropped by 10.1 percentage pointsfrom 49.3 percent in the earlier years of the study to 39.2 percent in the later years, likely a reflection of generational replacement. All age differences were significant at the .001 to .000 levels.

Other demographic variables had less effect on opinions concerning removing the racist's book. Whether or not respondents were parents had a small effect on opinions, with parents supporting removal at 37 percent compared to 30 percent of nonparents. Sex had little meaningful effect on opinion: Men and women were almost equally likely to support removal, at 33 percent and 37 percent, respectively. These differences for both independent variables were statistically significant at the .000 level.

The next research question asked, "Did geographic factors such as region of the country and place size affect respondents' opinions concerning book removal?" People who lived in the South $(\mathrm{N}=9,339)$ were most likely to support book removal (42.1 percent) compared to about one-third of those in the Midwest and the Mid-Atlantic (33.0 percent and 33.6 percent; $\mathrm{N}=$ 6,887 and $N=4,077), 29.8$ percent of those in the West $(\mathrm{N}=5,203)$, and 25.2 percent of those in New England ( $\mathrm{N}=$ 1,290). In all areas of the country except the South, respondents' opinions remained the same from the early to the later years of the study. In the South, support for removal dropped from 47.7 to 38.8 percent. While other studies have linked place size to conservative opinions - suggesting that people from rural areas and smaller towns are more conservative than people in cities-in this study place size only had a small effect on respondents' opinions. Support for removal by place size varied from 32.6 percent to 38.6 percent. Place size was examined in four divisions: 


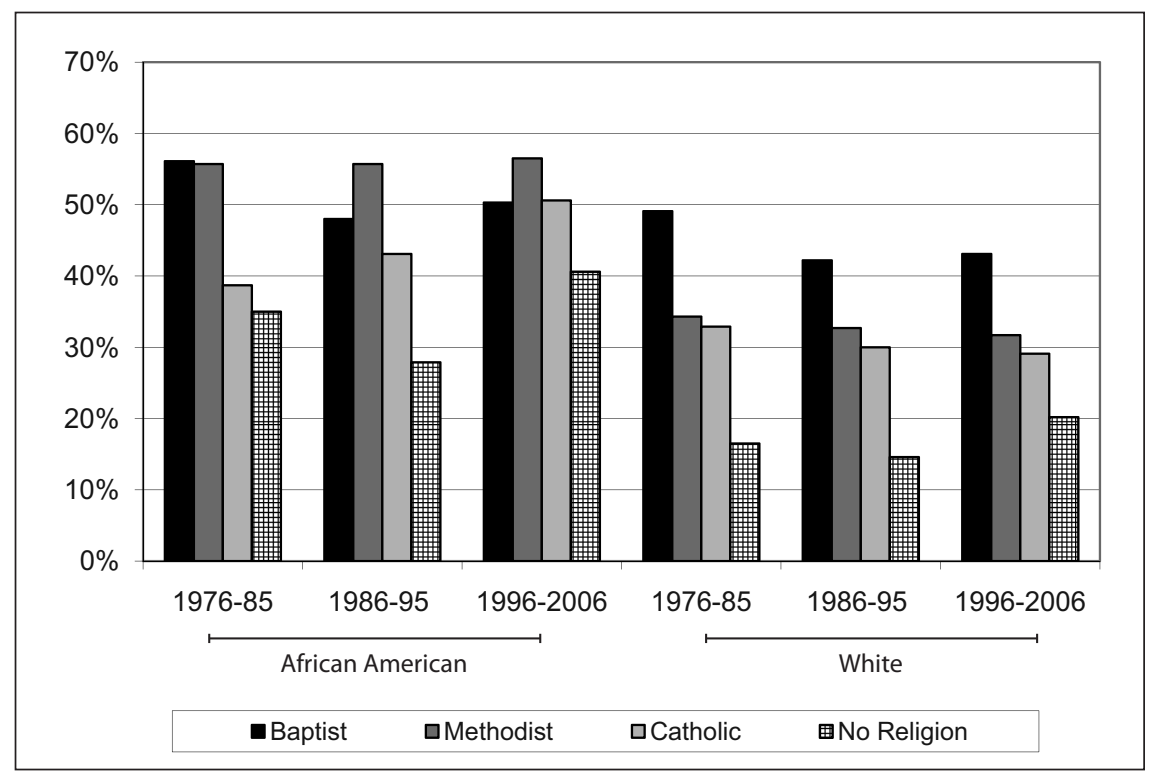

Figure 3. Support for Removing Racist's Book by Race (African American and White Respondents), Religious Affiliation, and Year

communities with fewer than 10,000 people, those with 10,000 to 99,999 , those with 100,000 to 999,999 , and those with 1 million or more. Differences by region of the country and place size were significant at the .000 level.

\section{Belief Systems}

The next research question asked, "What personal belief systems influenced people's opinions on book removal?" This section discusses respondents' religious affiliation and their political beliefs. Religious affiliation had an impact on approval of removing the racist's book. Respondents from the Protestant religions $(\mathrm{N}=15,993)$ supported removal at 39.5 percent compared to 32.3 percent of Catholics $(\mathrm{N}=6,830), 21.7$ percent of Jews $(\mathrm{N}=480)$, and 20.5 percent of those who claimed no religion $(\mathrm{N}=2,546)$. Within Protestantism, Baptists $(\mathrm{N}=5,477)$ were most likely to agree with book removal (47.6 percent) compared to 36.2 percent of Methodists $(\mathrm{N}=2,506), 30.4$ percent of Lutherans $(\mathrm{N}=1,630), 29.3$ percent of Presbyterians $(\mathrm{N}=1,095)$, and 24.7 percent of Episcopals $(\mathrm{N}=600)$. There were fewer differences between groups in the later years of the study, from a 23-point difference in support between Protestants and people with no religious affiliation in the early years, dropping to a 16-point difference in later years. This becoming slightly less likely to support removal (dropping from 41.8 percent to 38.8 percent) and respondents with no religion becoming more likely (increasing from 18.6 percent to 23.2 percent supporting removal). This drop over time among Protestants was almost completely because of a drop in Baptists supporting removal, from 51.7 percent in the early years to 45.8 percent in the later years. Differences by religion, denomination, and year were significant at the .000 level.

Within some religious denominations, race had a strong impact on their opinions concerning removing largest split by race, with 55.9 percent of African American and 33.1 percent of white respondents supporting removal (African Americans $\mathrm{N}=338$; whites $\mathrm{N}$ $=2,151$ ). Among those who claimed no religion, 35.7 percent of African Americans compared to 17.8 percent of white respondents supported removal (African Americans $\mathrm{N}=227$; whites $\mathrm{N}$ = 2,139). And among Catholics, 43.5 percent of African Americans supported removal compared to 30.8 percent of drop was related both to Protestants the racist's book. Methodists had the whites (African Americans N = 292; whites $\mathrm{N}=5,915)$. Among Baptists there was a much smaller difference by race: only 6.4 percentage points difference between African Americans (51.4 percent; $N=1,991)$ and whites (45.0 percent; $N=3,377$ ), although Baptists as a whole were more likely to support removal than other groups, predominately because of white respondents in this group being more likely to support removal than white respondents of other religions. These differences in support for book removal by religious variables and race were significant at the .000 level. There were not enough Lutheran, Presbyterian, Episcopal, or Jewish African Americans to allow a comparison for those respondents.

When comparing by race, religion, and year, there were a few changes over time. Dividing the data by this number of variables begins to result in small sample sizes, particularly for African American respondents, so many of these changes over time were not large enough to be statistically significant. Both African American and white Baptists dropped their support for removal by about 6 percentage points from the early to the later years of the study, and both of these changes were significant (whites $=49.1$ percent dropping to 43.1 percent; African Americans = 56.1 percent dropping to 50.3 percent). White Methodists and Catholics maintained their level of support at around onethird through the years of the study, but while African American Methodists maintained their support at about 56 percent, African American Catholics saw a jump in support for removal from 38.7 to 50.6 percent. The only change for Methodists or Catholics that was significant was for white Catholics. For both African American and white respondents, those who claimed no religion increased their support slightly over the years, and African Americans in this group were twice as likely to support removal. Neither of these groups' changes was statistically significant, with African Americans supporting removal at 35.0 percent increasing to 40.6 percent and whites supporting removal at 16.5 percent increasing to 20.2 percent (see figure 3 ). 


\section{FEATURE}

The difference in opinion by religious group may be related to education level: One-third of Baptist adults reported less than a high school education, compared to roughly 20 percent of Methodists, Lutherans, Catholics, and those with no religious affiliation; 14.1 percent of Presbyterians; 10.5 percent of Episcopals; and 8.1 percent of Jews. The differences in education level by religion were significant at the .000 level. However, when the author calculated opinions on book removal by religious affiliation with education level controlled, at every level of education Baptists were more likely to support removal than other groups, and Jews and those with no religious affiliation were least likely to support removal at the lowest education levels. At the bachelor's level of education, roughly one-third of Baptists supported removal, compared to about 10 percent of Episcopals and those with no religion and 20 percent of all other groups. At the graduate level, 23.9 percent of Baptists supported removal, compared to 8.3-16.9 percent of all other groups. The calculations in this section were statistically significant except for some junior college and graduate calculations. It can be concluded that both education level and religion had independent impacts on respondents' opinions concerning removal of a racist's book from the library.

Political affiliation and level of political conservatism had only a slight effect on respondents' opinions. By a small margin, Democrats were the most likely to support removing the racist's book (39.2 percent, compared to 34.0 percent of Republicans and 32.5 percent of independents). By political conservatism, 36.4 percent of conservatives, 37.7 percent of moderates, and 29.2 percent of liberals supported removal. These differences were statistically significant at the .000 level.

\section{Occupational Analysis}

The GSS data included two Census occupation variables, one that applied to the earlier years of the study and one that applied to the later years. The U.S. Census Bureau's 1970 occupation codes (occ70) were applied to surveys up to 1990. The 1980 occupation codes (occ80) were applied from 1988 forward. To calculate the following percentages, the author removed 1988 , 1989 , and 1990 figures from occ70 to avoid the overlap with occ80. Respondents were asked, "What kind of work do/did you do? That is, what is/was your job called?" The person explained their job, and the interviewer chose the Census occupation code that fit their explanation. It is important to note that the occupation category coded as "librarian" did not necessarily refer to respondents with an MLIS degree. In fact, of the respondents coded as librarians in this study $(\mathrm{N}=46)$, only 43 percent had a graduate degree and 37 percent had a bachelor's; the remaining 20 percent had high school educations. Additionally, 28 percent of college and university teachers had less than a graduate degree $(\mathrm{N}=179)$, and 24 percent of $\mathrm{K}-12$ teachers had less than a bachelor's $(\mathrm{N}=1,037)$. Therefore, while a job title might suggest professional education requirements to those in that field, the adherence to those requirements may be less than what is assumed. For the analysis by occupation, it was not possible to divide by year, as there were not enough librarians or library paraprofessional staff to compare if the categories were examined over time. Tests of significance were very applicable to analysis by occupation because these sample sizes were much smaller. The small sample size was a disadvantage for calculations concerning librarians and library staff ( $\mathrm{N}=46$ and $\mathrm{N}=36$, respectively) because statistically significant differences were unlikely.

Earlier in this analysis, education level was strongly correlated with opinions on book removal. In some instances, occupation had an effect beyond that of education level. Even though fewer than half of the librarians had master's degrees, they were less than half as likely as nonlibrarians with graduate degrees to support removing the book (6.5 percent compared to 15.3 percent).
This difference was not statistically significant, thus the numbers may not reflect an actual difference. While 83 percent of library paraprofessional staff members had high school educations, they were significantly less likely to support removal than other respondents with high school educations (19.4 percent compared to 35.5 percent). Library paraprofessionals supported removal at a rate comparable to occupations with bachelor's degrees. College and university teachers were less likely than other graduate-educated respondents in different occupations to support removal, but the difference was not significant. $\mathrm{K}-12$ teachers were significantly more likely to support removal than other occupations with bachelor's degrees, 26.6 percent compared to 20.0 percent. The differences between librarians, library staff, and college teachers were not statistically significant. However, librarians were significantly less likely than $\mathrm{K}-12$ teachers to support book removal (see figure 4).

\section{Regression Analysis}

In this section multiple regression analysis was conducted to determine the predictive value of the previously examined independent variables on opinions of book removal. The author examined the following variables to determine their ability to predict respondents' opinions: education level, race, age, parental status, sex, geographic factors, religious affiliation, political party, and political conservatism. Variables at the nominal levels of measurement were dummy coded for each variable value. The two ordinal variables, highest degree completed and age, were available in the dataset in slightly different forms as ratio level data, and these alternate variables were used in the regression because interval and ratio data are the most appropriate for regression calculations. These variables were age and highest year of school completed. Occupation was not used in the regression analysis, as this information was split between two variables in the dataset and the sample sizes in some categories were extremely small. 


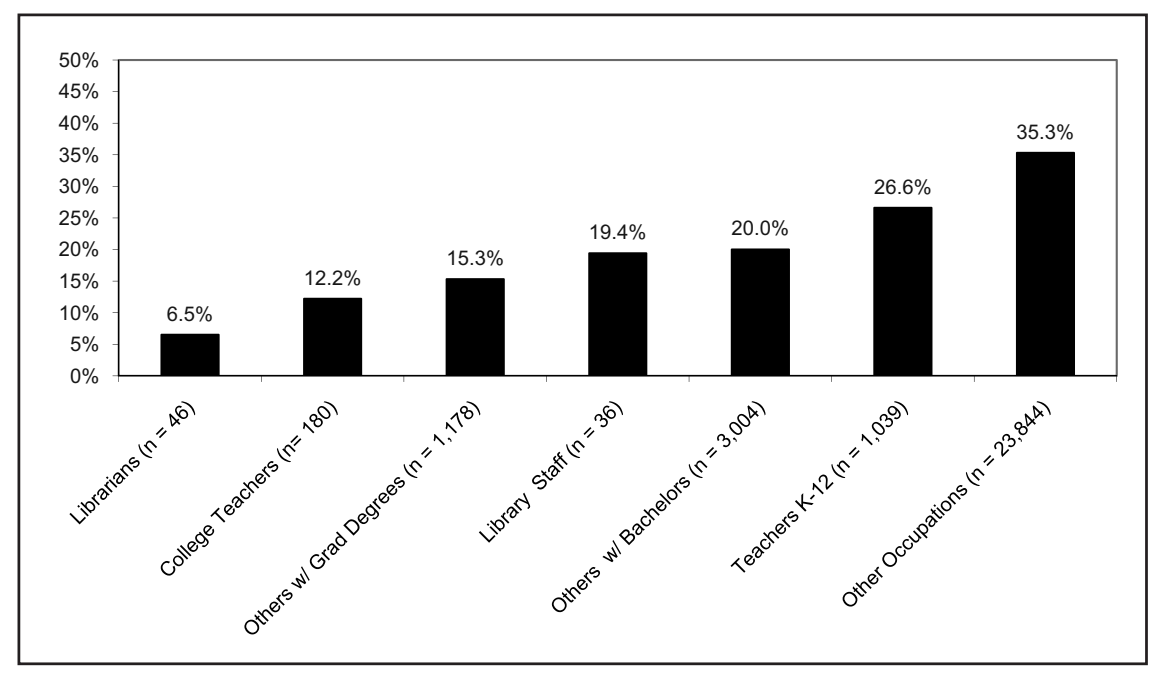

Figure 4. Support for Removing Racist's Book by Occupation

The regression results indicated that variables with the strongest predictive value on opinion were highest year of school completed, religious affiliation, race, and age. These variables were all significant in the regression equation at the .000 level.

In summary for the data analysis section, both the percentage analysis and the regression indicated that the most influential predictors of whether people would support removing a racist's book from the public library were education level, religious affiliation, and race. Age was also influential, particularly for older respondents. Occupation and living in the South were moderately influential. Political party affiliation, political views (liberal, moderate, or conservative), parental status, and sex only had a slight correlation with support for book removal.

\section{DISCUSSION}

As presented in the literature review, library policy and professional ideology is strongly supportive of intellectual freedom and retaining materials on controversial topics in library collections. Reflective of this was the data analysis in this study, which found that librarians were overwhelmingly against removing the racist's book, and library paraprofessionals were much less likely to support removal than other workers at similar education levels.

Since the majority of challenges are received on materials for children, it is perhaps not surprising that $\mathrm{K}-12$ teachers in this study were more likely to support removal than other workers with bachelor's degrees. As their professional lives revolve around children, they may be more likely to consider aspects of appropriateness when considering the racist's book.

Scholars in disciplines other than LIS were divided in their opinions toward the First Amendment rights of racist speech. Several of the reviewed enacted on U.S. college campuses in the late 1980s and into the 1990s. Such bans may have contributed to the increase in support for removal of the racist's book among the college educated, particularly among those with graduate degrees.

Racist speech and other hate speech can create a hostile social environment, and African Americans' experiences in such environments may make them more sensitive to the implications of the existence of the racist's book in the library. But while African Americans were more supportive of removing the racist's book than whites, it is important to note that in all but a few subcategories of analysis, the majority of African American respondents did not support removing the racist's book. This indicates materials mentioned hate speech bans a great deal of social tolerance on the part of African Americans. If future research were to ask about removing a library book denigrating white Americans, it would be interesting to see if white respondents would show similar levels of social tolerance.

Other research has indicated that religious variables are linked to social intolerance and book banning in public libraries. For example, Tamney and Johnson stated that "a consistent finding is that conservative Protestants are relatively intolerant, i.e., they are willing to restrict the civil liberties of controversial collectivities. . . In contrast, people who claim no formal religious affiliation are more tolerant." ${ }^{39}$ The religious variables that they found to be most highly correlated with willingness to ban books from public institutions were frequency of church attendance, fundamentalism, and moral traditionalism. They explained that these traditional ideologies lead to beliefs that humans are weak and cannot be trusted to make good decisions, thus censorship is an acceptable way to help people make the right decisions. They additionally found that "the book-banning scores were significantly higher among older, less educated, and politically conservative people." ${ }^{40}$ Tamney and Johnson did not use GSS data for their study; they interviewed five hundred people via telephone in fall 1993. The GSS data in this study showed that religious variables correlated with opinions on book removal, and when the author divided Protestants into different denominations it was found that the most conservative group was the Baptists, a group closely tied to religious fundamentalism. The GSS data also supported Tamney and Johnson's finding that older and less educated people were more willing to support removing the racist's book but did not find political conservatism to be strongly related.

For comparative purposes, it is instructive to contrast these opinions about the racist's book to controversial ideas of other types. The GSS contained additional questions about removing controversial books from libraries, for example a book on homosexuality 


\section{FEATURE}

written by "a man who admits he is a homosexual" and a book written by "a man who admits that he is a communist." Public opinion on the removal of these two books had different patterns over time than the racist book examined in this study. Concerning the homosexual's book, 44.5 percent of respondents supported removal in 1973 , and this dropped nearly in half to 24.1 percent in 2006. The most influential variables concerning the removal of the homosexual's book were education level and belief that homosexuality is wrong, followed by religious variables. There was no variation by race in support of removing the homosexual's book. ${ }^{41}$ The question about removing the communist's book was first asked in 1954, when 66.0 percent of respondents favored removal. ${ }^{42}$ When asked in the 1972 GSS, 44.0 percent supported removing the communist's book; this fell to 30.3 percent in 2006 . The most influential variables in support for removing the communist's book were education level and religious variables. African Americans were somewhat more likely to support removing a communist's book than whites. ${ }^{43}$ These changes in public opinion toward homosexuality and communism indicate increasing social tolerance toward these groups and toward the availability of books about them in public libraries. Education and religious affiliation were in the top three variables most highly correlated to support of book removal for all three controversial book types, underscoring the important impact of education and religious beliefs on people's social views.

The current study shows that the discomfiture of Americans over the free expression of offensive ideas about African Americans remained at a relatively constant level over the years of the study, although there were some shifts within particular demographic categories. That Americans held firm in their opposition to negative portrayals of African Americans, yet softened on their level of opposition to positive portrayals of homosexuals and communists suggests that while there was increasing social tolerance toward the civil liberties of suspect social groups to portray their ideals positively (such as homosexuals or communists), there was not a relaxing of attitudes toward the rights of people to denigrate other groups, such as African Americans. In other words, the presence of the racist's book was perceived as impinging on the civil liberties of African Americans and, in the opinion of about one-third of those surveyed, it should be controlled. Conversely, removing books on homosexuality or communism would impinge on the civil liberties of people in those groups. Consequently, as social tolerance increased, support for removing those books decreased. Racism is therefore perceived as a different type of social threat than homosexuality or communism. Since racism limits civil liberties of groups of people, some members of society believe that allowing a racist's book in the library is not in line with the social trend of increasing tolerance.

\section{IMPLICATIONS AND SUGGESTIONS FOR FUTURE RESEARCH}

The information in this study might be useful to librarians in a few ways. First, knowing how the library stance on intellectual freedom fits within the larger picture of scholarly thought from other disciplines and the broader public opinion is valuable. Secondly, studies have shown that during collection development it is not uncommon for librarians to engage in "self-censorship," not selecting items for the collection that they suspect might cause controversy and lead to a challenge. Whelan, for example, reported that in a recent School Library Journal study, 70 percent of school library media specialists said they would not purchase certain controversial titles because they wanted to avoid censorship conflicts. ${ }^{44}$ Twelve years earlier, Schrader had determined that various studies have shown that between 40 percent and two-thirds of public librarians have felt pressured to engage in self-censorship when choosing materials for their collections. ${ }^{45}$
Librarians can use the context presented in this paper to inform their collection-development decisions concerning materials containing racist content. Comparing the demographic makeup of the library community to the demographic predictors of support for challenges might help librarians predict the likelihood of challenges so that they can be prepared for a potential challenge in their library. Additionally, when facing challenges by individuals or facing opposition to library materials by boards of trustees or other official groups, librarians can use the data from this paper to support the collection-development decisions that led to adding the items to the collection.

The intention of this study was to provide information to the profession that may be useful when making decisions concerning intellectual freedom and controversial materials in libraries. Being knowledgeable about the issues surrounding potential materials challenges for racism can help librarians stand by their professional values and educate the public and library shareholders concerning the implications of removing or not removing such items from the collection. Adding excellent materials to the collection regardless of their potential to spark controversyand resisting challenges to such materials-is an important professional obligation of librarians, and it supports the principles established by the American Library Association. Best practices for preparing for and dealing with materials challenges are covered extensively in the library literature. This paper was not intended to dispute these recommendations, but instead to support them by providing insight into how nonlibrarians view the issue of books with racially offensive content in libraries. Recommendations for action are that librarians continue to serve their communities by maintaining rigorous professional standards and acting as champions of intellectual freedom.

Future research might include questions concerning materials with racist views of different groups to test whether different racist depictions cause different levels of support for removal. A 
question that determines whether the respondents are library users should be included. It would be very useful to differentiate between books on controversial topics for adults and those for children. Additionally, a question could be added that concerns whether the respondent has ever participated in a challenge of library material.

\section{References}

1. Barbara Froling Immroth, "Intellectual Freedom as Practiced by Public and School Librarians in Texas," Collection Management 7 (Fall 1985-Winter 1986): 353.

2. Kay Carolyn Saunders, "Factors Affecting the Outcome of Challenges to Library Materials [survey of public libraries belonging to the Northeast Texas Library System]," Texas Library Journal 68 (Fall 1992): 84.

3. American Library Association (ALA), "Library Bill of Rights," www.ala.org/ ala/issuesadvocacy/librarybill/index.cfm (accessed March 30, 2010).

4. Phylis A. Salak, "Objections to Gay Publications Prompt Policy Reexaminations," American Libraries 24, no. 4 (Apr. 1993): 287.

5. Jesse Shera, "Without Reserve: Intellectual Freedom-Intellectual? Free?" Wilson Library Bulletin 42, no. 3 (Nov. 1967): 323, 344-345.

6. Leigh S. Estabrook and Chris Horak, "Public vs. Professional Opinion on Libraries: The Great Divide?" Library Journal 117 (Apr. 1, 1992): 52-55.

7. ALA Office of Intellectual Freedom (OIF), Number of Challenges by Year, Reason, Initiator, and Institution, http://www.ala .org/ala/issuesadvocacy/banned/frequent lychallenged/challengesbytype/index.cfm (accessed Apr. 6, 2009).

8. Estabrook and Horak, "Public vs. Professional Opinion"; ALA, "Library Bill of Rights."

9. Holly G. Willett, "Rifles for Watie: Rollins, Riley, and Racism," Libraries \& Culture 36, no. 4 (Fall 2001): 487-505.

10. Gina Taylor, "Golliwogs: Harmless Fun or Racist Caricatures? Questioning a Childhood Favourite," Feliciter 52, no. 5 (2006): 218-19; Edwin S. Clay, "Censoring the New Millennium," Virginia Libraries 46, no. 1 (Jan./Feb./Mar. 2000): 6-9.

11. Willett, "Rifles for Watie," 487.
12. Pamela Hunt Steinle, In Cold Fear: The Catcher in the Rye Censorship Controversies and Postwar American Character (Columbus: Ohio State Univ. Pr., 2000): 4.

13. Dawn B. Sova, Literature Suppressed on Social Grounds (Banned Books) (New York: Facts on File, 1998): xix.

14. Ann Mulloy Ashmore, "Reflection on the Black Experience in Children's Literature," Mississippi Libraries 66, no. 2 (Summer 2002): 44-45.

15. Bernice A. Pescosolido, Elizabeth Grauerholz, and Milissa A. Milkie, "Culture and Conflict: The Portrayal of Blacks in U.S. Children's Picture Books Through the Mid- and Late-Twentieth Century," American Sociological Review 62 (June 1997): 443-64.

16. Taylor, "Golliwogs."

17. Willett, "Rifles for Watie."

18. Steven Fraser, ed. The Bell Curve Wars: Race, Intelligence, and the Future of America (New York: Basic, 1995): 1.

19. ALA OIF, Number of Challenges by Year, Reason, Initiator, and Institution.

20. Lee Burress, Battle of the Books: Literary Censorship in the Public Schools, 1950-1985, (Metuchen, N.J.: Scarecrow, 1989).

21. ALA OIF, Number of Challenges by Year, Reason, Initiator, and Institution.

22. Clay, "Censoring the New Millennium."

23. Nicholas Wolfson, Hate Speech, Sex Speech, Free Speech, (Westport, Conn.: Praeger, 1997): 1.

24. Bhikhu Parekh, "Hate Speech: Is There a Case for Banning?" Public Policy Research 12, no. 4 (2006): 213-23.

25. American Civil Liberties Union, "Hate Speech on Campus" (Dec. 31, 1994), www.aclu.org/free-speech/hate-speechcampus (accessed April 2, 2009).

26. Wolfson, Hate Speech, 102.

27. Ibid., 25.

28. Monteiro v. The Tempe Union High School District, 158 F.3d 1022 (9th Cir. 1998), quoted in Ann K. Symons and Sally Gardner Reed, Speaking Out! Voices in Celebration of Intellectual Freedom (Chicago: ALA, 1999): 28.

29. Harry White, Anatomy of Censorship: Why the Censors Have it Wrong (Lanham, Md.: Univ. Pr. of America, 1997): v.

30. Laura Beth Nielsen, License to Harass: Law, Hierarchy, and Offensive Public Speech (Princeton, N.J.: Princeton Univ. Pr., 2004): 1-2.

31. James Weinstein, Hate Speech, Pornography, and the Radical Attack on Free Speech Doctrine (Boulder, Colo.: Westview, 1999): 2-3.
32. Kristen Myers, Racetalk: Racism Hiding in Plain Sight (Lanham, Md.: Bowman \& Littlefield, 2005): 2.

33. Parekh, "Hate Speech," 218.

34. Joel David Bloom, "Still Here: The Persistence of Racism in Public Opinion, Voting, and Public Policy in the United States" (paper presented at the annual meeting of the American Association for Public Opinion Research, Pointe Hilton Tapatio Cliffs, Phoenix, Arizona, May 11, 2004), www.allacademic.com/meta/ p116110_index.html, (accessed Apr. 2, 2009).

35. James A. Davis, Tom W. Smith, and Peter V. Marsden, General Social Surveys, 1972-2006 [Cumulative File], computer file, ICPSR04697-v1 (Chicago: National Opinion Research Center [producer], 2007. Storrs, Conn.: Roper Center for Public Opinion Research, University of Connecticut/Ann Arbor, Mich.: Interuniversity Consortium for Political and Social Research [distributors], 2007).

36. James Allan Davis, Tom W. Smith, and Peter V. Marsden, General Social Surveys, 1972-2006: Cumulative Codebook (Chicago: National Opinions Research Center, 2007).

37. Ibid., 159.

38. Joseph B. Tamney and Stephen D. Johnson, "Christianity and Public Book Banning," Review of Religious Research 38, no. 3 (1997): 263-71.

39. Ibid., 264-65.

40. Ibid., 67.

41. Susan K. Burke, "Removal of GayThemed Materials from Public Libraries: Public Opinion Trends, 1973-2006," Public Library Quarterly 27, no. 3 (2008): 247-64.

42. Richard G. Niemi, John Mueller, and Tom W. Smith, Trends in Public Opinion: A Compendium of Survey Data (New York : Greenwood, 1989).

43. Susan K. Burke, "Works by Subversive Authors in American Public Libraries: A History of Public Opinion," forthcoming.

44. Debra Lau Whelan, "A Dirty Little Secret: Self-Censorship: Self-Censorship is Rampant and Lethal," School Library Journal 55, no. 2 (Feb. 2009): 26-30, www.schoollibraryjournal.com/article/ CA6632974.html (accessed Aug. 14, 2009).

45. Alvin M. Schrader, "Why You Can't 'Censorproof' Your Public Library: What Research Tells Us," Public Library Quarterly 61, no. 1 (1997): 3-30. 